\title{
Values of Islamic Economic System in Ritual "Mappadendang"
}

\author{
Abdul Rahim \\ STAIN Watampone \\ rahim_ilmi72@yahoo.co.id
}

\begin{abstract}
Cultural diversity that exists in Indonesia is one potential that must be developed and preserved throughout the cultures as long as they not incompatible with the moral values of Islam. In fact, this diversity provides vibrant colors varying as a tradition that characterizes respective tribes and ethnics. In the culture of the Bugis, one of the cultural or ritual that is routinely performed each year in agricultural activities (harvest) is mappadendang, attended by all farmers. This ritual is performed as a form of joy and gratitude on the Creator, for abundant agricultural crops. In addition to the form of joy, the mappadendang ritual also intended to preserve the cultural heritage of their ancestors. Mappadendang in Pinrang itself coins philosophical and religious values which are very high and are a means to strengthening the unity and integrity. The importance of cooperation within the traditional mappadendang ritual includes carrying values of the Islamic economic system, such as, to work earnestly for seeking halal earnings, to form solid society with solid social order, justice, income distribution, eradicating the monopoly, individual freedom in order to obtain social welfare.
\end{abstract}

\begin{abstract}
Abstrak
Keanekaragaman budaya yang ada di Indonesia merupakan salah satu kembanggaan yang harus dikembangkan dan dilestarikan sepanjang budaya itu tidak bertentangan dengan nilai-nilai ajaran Islam. Bahkan keanekaragaman ini memberikan warna hidup yang berbeda-beda sebagai tradisi yang mencirikan suku masing-masing. Dalam budaya suku Bugis, salah satu satu budaya atau ritual yang rutin dilakukan setiap tahun dalam kegiatan pertanian (panen) yaitu Mappadendang, yang diikuti seluruh petani. Ritual ini dilakukan sebagai bentuk suka cita dan kesyukuran pada sang Khalik, untuk hasil panen pertanian yang melimpah, selain bentuk suka cita, ritual Mappadendang juga dimaksudkan untuk mempertahankan warisan budaya leluhur. Mappadendang di Kabupaten Pinrang itu sendiri menyimpan filosofi yang sangat tinggi dan merupakan sarana nenek moyang dalam memperkuat persatuan dan kesatuan. Pentingnya kerjasama dalam ritual adat mappadendang termasuk melaksanakan nilai-nilai sistem perekonomian Islam termasuk menyuarakan kerja yang bersungguh-sungguh mencari rezeki yang halal, membentuk masyarakat dengan tatanan sosial yang solid, keadilan distribusi pendapatan termasuk menghapuskan monopoli, kebebasan individu dalam kesejahteraan sosial.
\end{abstract}

Keywords Islamic values, Islamic economy, local tradition, mappadendang 


\section{A. Introduction}

Indonesia is a country that has a diversity of cultures and tribes to be proud. This diversity provides vivid colors varying as a tradition that characterizes their respective tribes. Worldviews of different looks at the practice of everyday life both in terms of economic, social, cultural and political. ${ }^{1}$ Indonesian public life until now has been much influenced by outside culture, especially the cultural influence is still seen in many belief systems of society where the confidence gradually influenced by other beliefs. ${ }^{2}$

Every community has confidence in what lies outside itself as something beyond their power. In certain communities, a wide variety of events, such as natural disasters, outbreaks of disease affecting the community or agricultural land and various other events are believed to come from supernatural forces that inhabit certain places around them. Thus, to prevent such problems, people made a wide range of practices as a form of ritual offerings directed at the source or owner of such power. In addition, the trust people who have such power to make them perform various requests for the benefit or welfare of himself. There are also people who want a particular strength that they can use for a variety of things beyond the "ability normal" humans. This means that elements outside culture, especially on the belief system attached to the people of Indonesia to the area of religious practice. ${ }^{33}$

South Sulawesi is one part of the island of Sulawesi. Sulawesi island located in the eastern part of the Unitary Republic of Indonesia. South Sulawesi is one of the provinces which is located at the Southern tip of the island of Sulawesi. In the area of South Sulawesi toritorial in inhabited by four tribes, they are a tribe Bugis, Makassar, Toraja and Mandar. Although the tribe is now mandated located within the province of West Sulawesi, but its presence as clumps tribe in South Sulawesi still recorded neatly.

In tribal cultures Bugis Makassar, Islam as a religion Rahmatanlil Alamin not clash with tribal cultural Bugis Makassar ring, and so lead to

1 Wertheim, W.F .. Indonesian Society in Transition. (Yogyakarta: PT. Tiara discourse Yogya, 1999) p.1-2.

2 Koentjaraningrat. Culture, Mentality and Development. Jakarta: Gramedia Pustaka Utama: 2002) p. 21

3 Koentjaraningrat. Social and Cultural Anthropology; An Introduction. (Maumere: Ledalero: 2002) p.354 
the spread of Islam is not so heavy. Much of the literature that informs about tribal culture Bugis Makassar, informed that the tribe Bugis Makassar are devout Muslims, but on the sidelines of the compliance that there are some teachings that are still in use in various rituals such as when getting off the fields for the farmers or when it will sail or at the beginning of a new boat touch the sea for the fishing community. There appear elements of Islam which in combination with elements of public confidence in the past that still believe it until now.

Ritual is series of actions or deeds that are bound to certain rules based on customs, religions, and beliefs. The traditional ceremony is a ceremony performed hereditary prevailing in a society. The ceremony includes a variety of ritual practices in which the ritual reflects the meaning that can explain a ceremony held. So, the ceremony is an important ritual in the moment. While the ritual is defined as a social form of religion.

When defined religion as a system of understanding regarding the nature and the sacred, concerning life after death and so on (complete with a variety of political implications are obvious), then the ritual is a wide range of social processes that give concrete form to the understanding of the question. Generally, it can be said that the ritual is all manner of public events that are bound to the rules, which in one way or another to make thematization on the relationship between the earthly realm and the spiritual realm. ${ }^{44}$

In the tradition of the Bugis community that one of the rituals that are routinely performed each year in agriculture is starting from go to the field, plowing, until the time of harvest. There is Mappalili before plowing ceremony. There is Mappabenni ase before rice seedlings planted. This ritual is also used to do when storing rice seedlings in posi ball, a special place is located in the center of the house which is intended to ensure that none of the animals was passing over it. ${ }^{5}$

Bugis Mappadendang is customary for a long time, followed by all farmers. This ritual is performed as a form of joy and gratitude on the Creator, for abundant agricultural crops, in addition to the form of joy, ritual Mappadendang also intended to preserve cultural heritage of

4 Eriksen, T. H. Social and Cultural Anthropology; An Introduction. (Maumere: Ledalero: 2002) p.365

5 Mukhlis Paeni (et al). Leadership and Institutional in South Sulawesi (National Seminar papers HIPIIS. Ujung Pandang, 1996), p. 32 
ancestors who feared increasingly abandoned youth. Mappadendang is a traditional event the harvest festival of antiquity. Mappadendang is also interpreted as mappaccappu pammali, or starting reinforcements that at the time of entering the growing season until the next harvest, farmers continued prosperity and abundant harvests.

Mappadendang means to make sound or rhythm by using a mortar or "Palungeng", and usually played 9 persons. It's 6 women and 3 men. This party is usually done after a successful harvest. Dimples is actually a container made of tree logs to grind or crush something, such as grain, rice, sugar and others. Dimples begin to disappear along with technological advances in agriculture with their rice milling, rice processing plant so that the function of the mortar is replaced with the tool. ${ }^{6}$

Along with the modernization of farming systems and the orientation of the activity increase in "income" and national production. Finally, rituals are routinely held cultivation, gradually begin to disappear. So, the ritual system supporting agriculture are being abandoned. There is no longer harvested using ani-ani. There is no longer Katto Bokko. Nor are Kelong pare and Mappadendang. At the same time no more respect for the source of life. The practice of planting does not deal with the grace of Sri Sangiyang as had been believed. But the question of how agricultural products can achieve the production target expected national agricultural extension workers can work with the community in managing the fields. Based on the background described the formulation of the problem in this research are: What does the customary "Mappadendang" in Bugis society Pinrang mean and How is the implementation of values in a custom economics islamic System "Mappadendang",

\section{B. Principle of Discussion}

Mappadendang is one of the rituals which the population depends on farming business results. Mappadendang performed starts when the harvest arrives and do Katto bokko, harvest ritual that is usually accompanied with melon kelong. After going through a series of ritual was then performed Mapadendang. In the Bugis Makassar and surrounding communities ritual known by appadekko, which means adengka ase lolo, young rice pounding activities. Appadekko and Mappadendang purportedly indeed originated from this activity.

6 Mattulada, Culture Bugis Makassar, 275-77 
Therefore, within customary Mappadendang apparently has very philosophical significance is very high. In his book Muhammad Shafi Antonio $^{7}$, Bank Syariah: From theory to practice saying that there are some values of the Islamic economic system that is in accordance with traditional cultural Mappadendang, among others:

\section{Unity and Integrity}

For the Bugis community in Pinrang, Mappadendang ritual reminiscent of cosmology daily life of rural farmers hari. Mappadendang saves philosophies were very high which is an ancestor means to strengthen the unity and integrity ${ }^{8}$. The weakness of the unity of Muslims in Indonesia contributed to the economic slump of the people. Though the economy improves if the people of the unity of Muslims formed.

The coalescence and unity of Muslims that emerged strongly if there is true ukhuwah Islamiyya. Mean while ukhuwah Islamiyya only can be really materialized when Muslims are not mutually quarrel and arguing with each other but with how to stay as far as possible the differences that could undermine its unity and integrity.

Therefore unity and this is a manifestation of the economic system that is in synergy with the indigenous culture in mappadendang where the indigenous people bugis Pinrang. When doing this mappadendang custom look with a gathering of all people in the village. By the time people began to arrive and gather in a place that has been prepared by pemangkuh customs, and this activity is usually when the show placed in the fields, then that is where the house is set up farmers' groups which have always occupied mappadendang.

According to one community leader, that Ritual Mappadendang is a thanksgiving ritual for rice pane. This ceremony is a custom that originated from Bugis society from time immemorial. Upacara of age is usually done after the harvest when the dry season. This ritual is usually held at night. The main component in this event is 6 women, 3 men, booths Baruga, mortar, pestle, and traditional clothes are clothes Bodo.

\footnotetext{
7 M. Syafi'i Antonio, Bank Syariah from theory to practice, (Jakarta: Gema insani, 2001), p. 10

8 Nurhayati Rahman, Islam and Openness Pangngaderreng Papers, (International Seminar and Festival of Culture, Centre for Islamic Studies Centre For Middle Eastern Studies, Division of Social Sciences and Humanities PKP Unhas and the City Government of Makassar, 5-8 September 2007), p. 45.
} 
The women were in action in the booth called Pakkindona Baruga, was the man who danced and sow the tip of mortar called Pakkambona. Baruga booths made of bamboo, and has a fence made of woven bamboo called Walasoji. Upacara usually lasts until midnight. However, at certain events such as the opening ceremony and performances for foreign guests and tourists to do during the day. This tradition has been run for generations.

Everyone did mappadendang when the harvest had already come. But, this time the ritual is rarely done considering there is no more pare riolo and Katto bokko. Pare riolo is long term rice varieties with stems that grow higher. Longer than the new varieties that ever introduced by the government in the 1970s through agricultural intensification program, a wide PB-5 and PB-8 short-trunked.

During harvest time the residents are usually cut off the stalks of rice with ani-ani. Ani-ani is a cutter knife small size. If the rice is collected, usually rice crop yields will be knocked out by grinding in a lesung. Sound clash between wooden pestle, called a pestle and mortar is usually sounded loud. Forming a typical smart rhythm beats pounding. Movement and rhythmic sound of the collision that is the origin of art mappadendang. ${ }^{9}$

Unity into ropes that bind to and strengthen the Muslims. If the rope is broken, then vanished harmony and tranquility of disappeared. Interesting is necessary to assess the positive impact of unity in view of the Koran. This divine book looking for the security and the fabric of society and politics as the impact of the union. In a letter of Ali-Imran verse 103, Allah said,

"Hold fast to the religion of Allah and remain united. Do not do something that leads to division. Think about the gift of God that is revealed to you in the time of ignorance, while you still hostile. It was God unite your hearts through Islam, so that you become love. at that time you were in the abyss of hell, then God save you with Islam. with a good explanation like that, God always describes the way a favor for you to take. "

Based on this verse, divisions are an axis trigger war and bloodshed. On the other hand, the Koran also describes the constructive impact of the union to strengthen the pillars of society and social stability. When disputes and discord in society successfully completed, then the

9 Dr. H. Mansour (56 years old), Chairman of the STAI DDI Sidrap and Community Leaders in Pinrang, Interview, dated January 12, 2016, in Pinrang 
heart of every person is getting close to the other, and a row of people was getting stronger. So there is no chance for the enemy to influence social. Terkait this regard, Al-Quran surah al-Anfal verse 46 explains:

"Leave the disputes and conflicts that make you scattered and weak. Be patient in the face of all difficulties and obstacles in the battle. Allah is with those who patiently gave his support, affirmation and protection was good."

Al-Quran looked at factors that cause chaos in society is the existence of a dispute that can not be mitigated and resolved another groups. One unifying factor in Islam is their common goal. For this reason, the Koran calls upon Muslims believe that Islam is a total and obligations as well as leaving the ban. In Islam, there are many similarities that unite the followers of different schools. When all Muslims have similar views on many issues, especially in the pillars of Islam such as monotheism and the Prophethood of Muhammad.

Prophet saw unity as a source of good, otherwise the split is the source of this kesengsaraan. Terkait Prophet said:

"Unity is good and disunity is torture"10.

Prophet Muhammad forbade his people against each other and break up brotherhood. In fact, he strongly condemns the person who decides ties between fellow Muslims more than three days. When he was in the mosque of al-Khaif, he calls on Muslims to maintain brotherhood. Islam regards all human beings equally, regardless of race and ethnic groups. Prophet said, "Actually believers brothers, blood (race) they are equivalent, shoulders together (equip) and they are the upper hand in addition to them". ${ }^{11}$

On another occasion, the Prophet revealed parable Muslims in brotherhood and affection, like a human body, wherein when one of them felt ill, the other members will feel the pain too. In other parts, the Prophet Muhammad likens Muslims like children (teeth) comb flat and equal. He said, "The Muslims are equal like the teeth of a comb. Today the presence of more than 1.5 billion Muslims spread throughout the world, particularly in Islamic countries, including Iran into a bell threat to global hegemonic power. Since the appearance Islam is more than 1400 years, Islam has always been a bastion of unity in the face of an enemy conspiracy that

10 This Hadis hadith narrated from Ibn Umar, narrated by Ibn Majah, no. 2443; and alqudha'i in his Musnad, no. 774

11 Kulaini, Ushul Kafi, vol 1, p.333 
never subsided attacked Muslims in various ways since ancient times until now. ${ }^{12}$

\section{Cooperation}

In the tradition of Mappadendang priority to cooperation and unity in carrying out the work. Cooperation in work teams becomes a necessity in realizing the successful performance and work performance. Cooperation in work teams will be an impetus which has the energy and synergy for individuals who are members of the team work. Communications will run well based on an awareness of responsibility of each member.

According to community leaders in Pinrang that formerly, if anyone beating the mortar, all the direct neighbors flocked to the sound source. And they take turns to beating the mortar and the other doing something useful. Likewise, once the Bugis community, pounding rice if they help each other and occasionally they set the rhythm of the sound dimples as she stomped so engrossed heard. ${ }^{13}$

Islam teaches Muslims to helping (ta'awun), for example in the form of cooperation, as the word of Allah. Following .

"And help each other in the (working) virtue and piety, and do mutual assistance in sin and transgression" (Q.S. Al-Maidah: 2)

The condition above occurs is due to the absence of a solid unity of unity among Muslims themselves, so that the people ignored and marginalized economy. The strength of the Islamic brotherhood in essence can realize the unity of the people because of the affection, togetherness, social solidarity among fellow Muslims are able to realize better economic community.

Cooperation in the agricultural business, in Islamic economics Known as:

\section{a. Al muzara'ah}

Al-muzara'ah linguistically derived from the Arabic word $a z-z a r^{\prime} u$ basis. $A z-z a r^{\prime} u$ own words have two meanings, the first meaning is tharh

12 Majlisi, Bihar al-Anwar, vol, 97, p.72..

13 H. Ambo Sakka (72 years old), Community Leaders, Interview, dated January 19, 2016 in Pinrang. 
$a z-z u r^{\prime} a h$ that means throwing the seed (in other words, from az-zur'ah is al-budzr), namely throwing seeds into the ground. ${ }^{14}$

In terms of agricultural processing muzara'ah is cooperation between land owners and tenants of land with an agreement for the number of results according to the collective agreement, but generally paroan paddy for land owners and tenants of land. ${ }^{15}$

According to Sheikh Muhammad Yusuf Qordhawi, muzara'ah is landowners to surrender the tools, seeds and animals to to be planted with a provision she would have a predetermined outcome, for example: $1 / 2$, $1 / 3$ or less or more by mutual consent. ${ }^{16}$

In the book al-Umm, Imam Shafi'i explained that the Sunnah of Rasul implies two things: first, the meaning muzara'ah; bermuamalah skill on the palm tree / allowed to transact on the ground and what was produced. This means that there has been a new palm tree then handed to the nurse (employees) to be treated until fruition. But before the two sides (plantation owners and workers) should first agree on revenue sharing, that most of the fruit to orchard owners were others for workers.

Second; prohibition muzara'ah with the division of the $1 / 4$ and $1 / 3$ or part by part. The point is to hand over vacant land and no plants in it and then the land was planted by (tenants) with other plants. ${ }^{17}$ Here is a rewarder muzara'ah meaning and may not be someone to give wages to others for his work except with wages that can already be known by both before workers begin work. This is the meaning muzara'ah described in the Sunnah.

Then Imam Shafi'i also defines Mukhabarah with:

"Muzara'ah is the delivery of agricultural land to a farmer to be processed and the result divided by two"18.

Muzara'ah is working on the ground to obtain some of the results, were seeds (seeds) are used belong to the land owner, are not allowed

14 Wahbah Zuhaily, Al-Fiqhu wa al-Islamu Adilatuh,(Lebanon Beirut: Dar al-Fikr, t. th,) p. 613 .

15 Masyfuk Zuhdi, Masail fiqhiyah (Capita Selecta Islamic Law), (Jakarta: PT. Toko Gunung Agung, 1997), p. 130

16 Syekh Muhammad Yusuf Qaradawi, Halal and Haram in Islam, (Jakarta: PT. Bina Sciences, 1993). p. 383

17 Imam Abi Abdillah Muhammad ibn Idris ash-Safi'i, al-Umm, the Section III, Egypt: Dar alFikr, t.th, p. 12.

18 M. Ali Hasan, Various Transactions in Islam, (Jakarta: PT. King Grafindo Persada, 2003), p. 272. 
because of unauthorized lease land with the results obtained from him, so that mu'tamad the Shafi'i school of thought before Ulama 'Shafi'ites allow equal to Musaqoh (hirelings). ${ }^{19}$

According Badaruddin in "Mukhtasar al-Fataawa al-Mishriyah

Li Ibn Taymiyyah "that muzara'ah to land in exchange for half of the crop is permissible, both seedlings coming from the owner of the land or of the workers. ${ }^{20}$

So, from some of the above definition can be concluded that muzara'ah by language means muamalah on the ground with parts that came out a portion of it. But in terms muzara'ah is an agreement of cooperation in the processing of agricultural land or plantations between land owners and tenants with appropriate sharing agreement of both parties.

\section{b. Al-Musaqah}

Musaqah is a simplified form of muzara'ah where the tiller is only responsible for watering and maintenance. In return, the tenants are entitled to a certain ratio of the crop. ${ }^{21}$

Musaqah ie assign a worker to pepohon to him keeping with irrigate them and pay attention to their interests. Because irrigate the crop is a work which bring benefits, then assigned him an agreement, which is where all the friends and the tabi'in agreed to allow it without any mistake again. $^{22}$

However, in another study said that the so-called tree of the matter is: All that is planted in order to survive for a year or more, for the time that there are no provisions, and finally in emotongan / logging. Good trees bear fruit in the form musāqāh or not. Cooperations in musāqāh differ by hiring a gardener to take care of the plants, as a result of which he received was wages has definite size and not of the outcome, not necessarily.

\section{Intention sincere}

With sincere intentions, all forms of activity are permissible (mundane job) turned into worship. His life will change as well be a regular

19 Tengku Muhammad Hasbi Ash Shiddieqy, the Laws of Islamic jurisprudence, Semarang: Reader Rizki Putra, 1997, Cet. to-1, hlm.125.

20 Syekh Badaruddin, Mukhtashar al-Fatawa al-Mishriyah Li Ibnu Taimiyah, (Beirut Libanon : Dar al-Kutub al-Ilmiyati), t.th, p. 364

21 Muhammad Shafi Antonio, Bank Syari'ah from Theory to Practice, (Jakarta: Gema Insani Press, cet. 1st, 2001), p. 100

22 Imam Taqiyuddin, Kifayatul Ahyar, bag. 1, trans. Syaifuddin Anwar, (Surabaya: Bina

Faith, cet.ke-2, 1995), p.688.. 
life or cosmopolitan, containing a variety of obedience and approaches to Allah swt. ${ }^{23}$ In the Bugis ethnic society, where activity is an activity mappadendang hereditary always held each year for the celebration party of agriculture. This activity is an activity that are sincere and do not have a political element in it, this event truly have nuanced togetherness in carrying out the celebration with intention and sincere.

According to interview village leaders Madello Pinrang said that the activities of this mappadendang have the meaning which it has a high enough nuangsa accompanied with sincere with the intention that wrote that this activity has the feel full of religious worship ${ }^{24}$. In the word of God:

"And I did not create the jinn and mankind except to worship me".

Hadith Prophet Muhammad:

"Verily deeds it depends intention, and indeed each person received a reply from sesusai actions with intentions ${ }^{\prime 25}$.

What is meant by the intention in this context is the desire either to others and yourself. Good wishes to yourself, such as always keeping yourself from illicit possessions, keep yourselves from humiliation begging, steeling himself to the worship of God, keep in touch and relationships relatives, and various forms of other virtues.

However, the good wishes of others, that contribute to meet the needs of society in which the act is counted fardhu kifayah, giving the opportunity to work with others to liberate themselves on what is desirable for them to they themselves, in the same way. Thus also contributing to free people from dependence on others.

\section{Rightfull Business}

God justifies the good things to His servants and forbids the bad things. Therefore, this concept in customary mappadendang have values that are kosher, because the infrastructure is used in the mappadendang are goods coming from all communities in villages occupied indigenous mappadendang celebrate. This means that all goods used naturally derived from halal goods.

23 Shalah ash-Shawi and Abdullah al-mushlih, financial economics Islamic Jurisprudence, (Jakarta: Darul Haq, 2008), p.1-2

24 Lakandu (67 yrs), Community Leaders, Interview, dated January 25, 2016 in Pinrang.. 25 Muttafaq "Alaih of hadith Umar bin al-Khattab: narrated by al-Bukhari in the book bad'ial wahyl, chapter kaifa bad'I al-wahyi, no. 10; and the Muslim book of al-Imarah, chapter qauluhu "innama al-bian a'mal-Niyati no. 1907 
According to a figure of the community leaders in Pinrang that the use of facilities and infrastructure conducted on mappadendang activities are halal goods, including food used during traditional celebrations mappadendang. ${ }^{26}$ Therefore, in the hands of Muslim property will not turn into a tool wrecking people's lives, destroying homes and damaging prosperous generation is born. Treasure obtained by lawful business that will function as desired by Allah, rabb of all creatures. It uses energy radiating, grow and develop a force that contains various virtues and gifts, keep the spring that always exudes a blessing and a pleasure, so that all the people are happy, because the business benefits can be felt by the whole community. ${ }^{27}$

\section{Allah says:}

"And (God) justifies all that is good for them, and forbids those bad things and get rid of their burdens and the shackles that exist on them. Then the people who have faith in Him, glorify him, help him and follow the bright light that revealed to him (Al-Qur'an), they are the ones who are lucky "(Al-Araf: 157)

\section{Allah said:}

"Let's say, is not the same the bad with the good, although plenty of the evil attract thee, so fear Allah, $O$ men of understanding, that ye may profit" (Al-Ma'idah: 100)

Poor expression can apply to words and deeds statutes or rejection which Allah and His apostles.

\section{Accomplishing Rights}

A Muslim would hasten to performing rights others, be it wages, or debt to the other party. A worker must be paid before his sweat dried. Thus every effort is required to create a system that is oriented hasten the fulfillment of these rights. Such as accelerating payment or pay it at the time determined. ${ }^{28}$ Because the Prophet Muhammad said:

"Give the workers wages before his sweat down"

And he (the Prophet Muhammad) also said:

26 Shalah ash-Shawi and Abdullah al-mushlih, financial economics Islamic Jurisprudence, (Jakarta: Darul Haq, 2008), p.6-7

27 Shalah ash-Shawi and Abdullah al-mushlih, financial economics Islamic Jurisprudence, (Jakarta: Darul Haq, 2008), p.6-7

28 halah ash-Shawi and Abdullah al-mushlih, financial economics Islamic Jurisprudence, (Jakarta: Darul Haq, 2008), h.7

29 This Hadis hadith narrated from Ibn Umar, narrated by Ibn Majah, no. 2443; and alqudha'i in his Musnad, no. 774 
"The attitude of the rich are slowing repayment is kezhaliman"130

\section{Justice and Brotherhood Whole}

In the ritual Mappadendang Bugis culture, strata between the land owners and their laborers alike. Farmers who have vast rice fields or just a patch yet, in this ritual is considered no different. Islam aims to form a community with a solid social order. In that order, each individual is bound by brotherhood and love for a family. A universal brotherhood and not tied geografis. Justice in Islam has implications as follows: ${ }^{31}$

\section{a. Social justice}

Islam considers humanity as one family. Hence all family members have the same degree in the presence of God. God's law does not distinguish between rich and poor as well does not distinguish white with black.

\section{b. Economic justice}

The concept of brotherhood and equal treatment must be offset by economic justice. Without offsetting them. Social justice will lose their meaning. With economic justice every individual will get its due in accordance with their respective contributions to the community. Each individual must also be free darieksploitasi of other individuals. Islam strictly forbids a Muslim to harm others.

\section{Justice Income Distribution}

The income gap and the natural resources that exist in society against the spirit and Islam commitment to brotherhood and socioeconomic justice. The gap must be overcome by using a method that is emphasized Islam include the following ways: ${ }^{32}$

a. Eliminate monopoly, except by the government for specific areas.

b. Ensure the rights and opportunities of all parties to be active in both the economic process of production, distribution, circulation and consumption.

c. Guarantee the fulfillment of basic needs (satisfaction of basic needs of life) every member of society lives.

d. Implementing this mandate at-takafaful al-ijtima'i economic security or social insurance which are able to bear and help the unable. In this

30 Hadis narrated from Malik in al-Muwatta, 2/674 al-bukhari in the book narrated by al-Hiwalah no. 2887; and Muslim no. 3345

31 M.Syafi'i Antonio, Syariah Bank from theory to practice, (Jakarta: Gema insani, 2001), p.13-15.

32 M.Syafi'i Antonio, Bank Syariah from theory to practice, (Jakarta: Gema insani, 2001), p.15-16. 
way individual living standards will be more secure. The human side and honor each individual will be maintained in accordance with the dignity inherent to human beings as a vicegerent of God on earth.

According to community leaders say that the traditional concept of this mappadendang meaning of justice in it, including all the people in the village were occupied implement mappadendang celebration to indirectly spontaneity in giving its contribution to the implementation of the cultural activities. $^{33}$

Therefore, activity mappadendang has a philosophical meaning that is quite large, so that all activities undertaken community Pinrang especially in the celebration of indigenous mappadendang this was not contrary to Islamic values, even in line with the economic concept of syari'ah that have nuanced helping, consensus, unity and equal justice.

\section{Conclusion}

Along with the modernization of farming systems, traditions Mapadendang are increasingly rare. Whereas in the sense of ritual that farmers appear. Mappadendang culture has a philosophy that is very high, because it has the elements of deliberation, friendship and prayer. In addition Mappadendang also has economic elements which correspond with the concept of Islam, including the strengthening of unity, the importance of cooperation in carrying out the work (cooperation in the processing of agricultural land or plantations between landowners and tenants sharing system according the agreement of both parties), intention genuine, lawful business, performing rights, justice and fraternity thorough, distributive justice pendapatan. Budaya Mappadendang still expected its existence, because it does not clash with the teachings of Islam as a religion Rahmatan lil alamin.

\section{References}

Farid A. Zainal Abidin, Indigenous and Tribal Culture In Bugis in South Sulawesi.

33 Salahuddin (68 yrs), community leaders, Interview, dated January 18, 2016 in Pinrang 
Eriksen, T. H. 2002 Social and Cultural Anthropology; An Introduction. Maumere: Ledalero:

Abi Abdillah Imam Muhammad ibn Idris ash-Safi'i, al-Umm, the Section III, Egypt: Dar al-Fikr

Koentjaraningrat. 2002. Culture, Mentality and Development. Jakarta: Gramedia Pustaka Utama

Koentjaraningrat. 2002 Social and Cultural Anthropology; An Introduction. Maumere: Ledalero

Mattulada, Culture Bugis Makassar: 275-7

Muhammad Shafi Antonio, Bank Syariah: From Theory to Practice, Jakarta: Gema insani, 2001

Mukhlis Paeni (et al) 1996 Leadership and Institutional in South Sulawesi HIPIIS National Seminar papers. Ujung Pandang.

Nurhayati Rahman. 2007. Papers Islamic Shari'a and Openness Pangngaderreng, (International Seminar and Festival of Culture, Centre for Islamic Studies Centre For Middle Eastern Studies, Division of Social Sciences and humanities PKP Unhas and the City Government of Makassar, 5-8 September)

Majlisi, Bihar al-Anwar, vol, 97, p.72.

Masyfuk Zuhdi. 1997. Masail fiqhiyah (Capita Selecta Islamic Law), Jakarta: PT. TokoGunung Court,

M. Ali Hasan. 2003. Various Transactions in Islam, Jakarta: PT. King Grafindo Persada,

Salah al-Shawi and Abdullah al-mushlih. 2008. Islamic Jurisprudence financial economics, Jakarta: Darul Haq.

Sheikh Muhammad Yusuf Qaradawi. In 1993, Halal and Haram in Islam, Jakarta: PT. Bina Science, 
Tengku Muhammad Hasbi As- Shiddieqy. 1997, the laws of Islamic jurisprudence, Semarang: Library Rizki Putra.

Wahbah Zuhaily, Al-Fiqhu wa al-Islamu Adilatuh, Lebanon Beirut: Dar al-Fikr, t. th,

Wertheim, W.F. 1999. The Indonesian Society in Transition. Yogyakarta: PT. Tiara acana Yogya, 